\title{
ZPRÁVY
}

\section{Sociologický pohled na transformaci polské společnosti}

Devátý sjezd polských sociologů, konaný roku 1994, se věnoval převážně změnám, jimiž polská společnost prochází při tvorbě nového řádu. Dvoudílný protokol, který byl před časem $\mathrm{z}$ tohoto sjezdu vydán (Ludzie $\mathrm{i}$ instytucje. Stawanie sie ładu spolecznego. Pamietnik IX Ogólnopolskiego Zjazdu Socjologicznego, Lublin 1995), poskytuje na svých více než sedmi stech stranách svědectví o rozsahu i hloubce pohledu, jehož jsou polští sociologové v přistupu $\mathrm{k}$ současné vlastní společnosti schopni. Předmětem zájmu se stala dynamika všech základních součástí společenského života od politiky a ekonomiky, přes sociálni strukturu až po svět hodnot. Stranou nezůstal a ani sebereflexe vlastního postavení sociologů $v$ transformující se společnosti a změny jejich sociálních rolí.

$\mathrm{V}$ této informaci se zaměřím na několik problémových okruhů, jež ve svých přispěvcích synteticky a $\mathrm{z}$ hlediska stavu současného zkoumání dané tematiky $v$ Polsku asi nejreprezentativněji zpracovali tři přední polští sociologové. Jde o problematiku, která mủže být zajímavá i svým případným srovnáním $\mathrm{s}$ obdobnými procesy, jež probíhají u nás.

Hledáni jazyka transformace a hlavnich aktérủ nového řádu

$\mathrm{V}$ nadpisu obsaženými otázkami se ve svém vystoupení Lidé a instituce. Kdo tvoří nový řád? zabýval ředitel Institutu filozofie a sociologie Polské akademie věd Andrzej Rychard. Autor nejprve upozorn̆uje na to, proč je problém jazyka transformace závažný a proč vyvolává $\mathrm{v}$ polské sociologii, ale nejen v ní, charakteristické těžkosti. Na jedné straně se totiž zdá, že situace téměř revolučni změny musí vést také $\mathrm{k}$ revoluci paradigmatické, která by zahrnovala nové koncepce, teorie i nový jazyk popisu skutečnosti. Na druhé straně však jde alespoň částečně o revoluci ve jménu návratu $\mathrm{k}$ normalitě, tzn. že transformace má vytvořit řád založený na principech demokracie a kapitalismu, jež jsou přece známé už dávno. Proto by se mohlo zdát, že není ani tak třeba hledat nové kategorie a jazyk, ale spiše teprve nyni oprávněně aplikovat klasické sociologické koncepce. Tím je do jisté míry možné vysvětlit absenci zásadních ideových diskusí. Vracíme-li se totiž $\mathrm{k}$ tomu, co je „Známé“, nejsou ideologické diskuse o cílech potřebné, postačí pragmatické hledání účinných prostředků.

Polská sociologie se podle Rycharda pohybuje mezi těmito dvěma stanovisky a těžkosti, které brání nalezení adekvátního jazyka, plynou $z$ výše zmíněné dvojznačnosti. Jde o to, jak popsat revoluci ve jménu návratu.

Autor tímto dilematem ospravedlňuje a zároveň zdůvodňuje strategii nebo spiše konvenci popisu, kterou přijal. Domnívá se, že dnes mưže sociologie při zkoumání transformace nejvíce dosáhnout, když se soustředí na popis konkrétního, na důkladné pozorování. Hovoři pro to podle něho snaha vyvarovat se teleologického modelu analýzy transformace a věnovat pozornost pluralitě transformací, jakož i závažnost lokální perspektivy jejich studia.

Za zvlášt' dủležitou považuje dnes Rychard institucionální rovinu analýzy, přičemž upozorňuje, že právě zde má polská sociologie bohatou tradici. Spolu s postupným opouště- 
ním ,tradičního" paradigmatu, soustřed'ujicího se na makrosystémovou problematiku, se stále silněji pocit’uje význam „středni" úrovně, tj. institucí a organizaci i jejich analýz. Zčásti to plyne $z$ toho, že institucionální aspekt přeměn je obvykle považován za nejméně rozvinutý, přičemž autor upozorn̆uje na paradox spočivající v tom, že Polsko je sice zemí neustále se rodících nových organizací, jako jsou firmy či politické strany, ale zároveň se často objevuje názor, že transformace je „slabě institucializovanác a že změny se v podstatě týkaji dvou extrémů: makropolitiky a každodenního života občanů, zatímco instituce „středni" úrovně jsou nejslabším článkem. Jedním z hlavních cílů Rychardova príspěvku právě je tento paradox vysvětlit.

Autor vytyčuje základní otázku, kdo tvoři nový rád: lidé, nebo instituce? Zároveň si uvědomuje její zjednodušující charakter. Dodává proto, že ho zajímá spíše porovnání racionality a jednání jedincủ s institucionálními podmínkami jejich realizace. Protože otázka, zda jsou hlavními aktéry „nového“ jedinci, nebo instituce, může dráždit svým normativismem, bude Rychard $\mathrm{z}$ analytických důvodů raději hovořit o srovnávání individuálního chování $s$ institucionál ním kontextem, $\mathrm{v}$ němž probíhá

Tak se konstituují tři klíčové problémy, jež se autor pokouší řešit: Do jaké míry jde o přizpůsobeni a do jaké míry o konflikt? Přetrvaly staré adaptační mechanismy přizpůsobující svět institucí světu individuálních zkušeností zájmů a aspirací? $V$ jakém stupni jsou tyto adaptační mechanismy faktorem změny a v jakém naopak konzervují staré zájmy a institucionální struktury?

Rychard háji tezi, že během transformace dochází $\mathrm{k}$ dekompozici triády tvořené lidmi (neboli individuálními a skupinovými aktéry), organizacemi a institucemi, přičemž $\mathrm{v}$ souladu $\mathrm{s}$ názorem $\mathrm{D}$. C. Northa pod institucemi chápe soubory opakovatelných pravidel a norem a pod organizacemi zformalizované aktéry, kteří tyto normy aplikuji v praxi. Ačkoli se podle Rycharda transformace týká každé $z$ těchto rovin analýzy, chronologie změn není pro všechny stejná, což nutí odmítnout teleologický a lineární model transformace, podle něhož jde o prostý, na jasný cíl zaměřený přechod od starého režimu $k$ trhu a demokracii.
Zatímco pád dřivějšiho systému byl vynucen masami a probíhal za určité tolerance starých institucionálních elit a první etapa transformace byla vedena novými elitami za určité tolerance společnosti, později už ani elity, ani velké sociální skupiny hlavními aktéry nebyly a dodnes nejsou. Nestaly se jimi ani organizace a těžiště se přesunulo na jedince a mikrosystémy kolektivního života.

Dekompozice výše zmíněné triády podle Rycharda znamená, že každá z jejích složek má odlišnou logiku jednání a racionality. Odlišná je rovněž úroveň „transformační pokročilosti" každé z nich. Autor zároveň háji názor, že hlavními aktéry „výstavby nového rádu“ jsou spíše jedinci a skupiny (někdy díky př́znivým novým institucionálním pravidlům) než organizace.

Rozhodující roli při pádu starého režimu sehrály takové organizační síly jako odborový svaz a sociální hnutí Solidarita, katolická církev a velké státní podniky. Podle autora je však možné odůvodněně soudit, že hlavním institucionálním zájmem žádné z nich není budování kapitalismu nebo parlamentní demokracie. Je totiž těžké očekávat, že by odborový svaz, mocná náboženská instituce nebo velké státní podniky mohly být průkopniky nového rádu. Vedle nich však existují dobře zorganizovaní představitelé těch sil, které svou genezi vyvozuji $\mathrm{z}$ dřívějšího systému. Takto nastíněný obraz znázornuuje (podle autora zajisté poněkud vyostřeně a zjednodušeně) organizační i institucionální osamocenost aktérů výstavby nového.

Ti byli hlavními činiteli už v první etapě transformace (1989 - polovina roku 1990), kdy se úspěšně realizoval tzv. Balcerowiczův plán, který zásadními centrálními monetaristickými rozhodnutími vytvořil institucionální podmínky pro racionalizaci chování individuálních spotřebitelů i domácností. Nadto bylo často konstatováno, že díky uskutečňování tohoto plánu se více změnilo a racionalizovalo právě chování individuálních konzumentủ než podniků. Proto Rychard souhlasí s těmi autory, kteří tvrdí, že to byly spíše zájmy lidí jako spotřebitelů a daňových poplatníků než jako zaměstnancủ, které reformy a změny uváděly do pohybu.

Podle Rycharda však existuje ještě jeden faktor posilující roli individuálních a skupino- 
vých aktérů ve výstavbě nového řádu. Od poloviny roku 1990 začala klesat politická podpora nových mocenských orgánů. Distance od politiky a nechut' $k$ ní však vůbec neznamenaly pasivitu. Naopak, aktivita se pouze presunula do mikrosféry a do sféry lokální. Rodiny a jedinci donucení potýkat se s transformací si vypracovali standardy, jak si s ní racionálně poradit. Začaly se objevovat různé lokální iniciativy a dozrávat rozličná sociální hnutí. Jejich charakteristickým znakem je, že se ještě nepřeměňují v politické jednání. Aby vyjádřili a realizovali své zájmy, nehledají lidé politické organizace. To je však podle Rycharda dočasné. Nelze totiž vyloučit, že budoucí politika vyroste $\mathrm{z}$ toho, co je dnes mimopolitické. Autor je přesvědčen, že se v rámci této aktivity vytvářeji zárodky občanské společnosti.

Rychard chápe procesy, které dnes v Polsku probíhaji, jako jakousi směs toho, co bylo a co se nově zavádí. Tento hybrid má určitou vnitřní logiku, která vytváři základy nového institucionálního rádu a činí samo rozlišení starého a nového málo zřetelným. Klíčová otázka zní, zda se transformace ve smyslu svého institucionálního vývoje zastaví v současné etapě, nebo zda se objeví nové impulzy změn. Podle polského sociologa by první alternativa znamenala ,předčasnou konsolidaci“. Ta však není vyloučena, pokud politika bude tak slabě sociálně zakořeněna, jako je tomu doposud. Pak bude souladu individuálního chováni, organizačních a institucionálních struktur dosaženo prostřednictvím jakýchsi neokorporativistických řešení a společnost zůstane i nadále mimo politiku.

Není však vyloučeno, že zárodky nového na úrovni lokálních aktivit své místo $\mathrm{v}$ politice i cestu $k$ ní naleznou. Podle některých badatelů probíhá totiž v Polsku rekompozice sociální struktury spočívající ve spojování faktorů statusu, které je silnější než dřive. Zásadní význam zde má rostoucí korelace mezi formálním vzděláním a výdělky. Směřování $\mathrm{k}$ meritokratické společnosti s graduální strukturou by podle Rycharda znamenalo vytváření silného pravidla spojujícího zájmy jedinců a organizací a bylo by krokem $\mathrm{k}$ institucionalizaci. Tak by zmíněná rekompozice mohla být i počátkem rekompozice triády aktérů, organizací a institucí.

Stále však hrozí i vize společností dvou světů: té, která se na dobrodiních transforma- ce podilí, a té, která je marginalizovaná. Otáz$\mathrm{ku}, \mathrm{zda}$ Polsko směřuje ke graduální společnosti, nebo ke „dvěma společnostem“, považuje Rychard pro budoucí institucionální řád za klíčovou.

Výstavba takového nového řádu, který spojuje zájmy jedincư, formální organizace a institucionální pravidla, a vše to činí tak, že podněcuje modernizační jednání, je cílem neobyčejně obtížným, ale také atraktivním. Je $\mathrm{k}$ tomu nutná organizační i institucionální podpora dnes poněkud osamocených proreformních zájmů.

Závěrem autor vyjadřuje názor, že $\mathrm{z}$ dnešní mimopolitické aktivity, vytvářející se po vyčerpání mise Solidarity, mưže vyrůst budoucí institucionální rád. Mohou se však objevit i překážky. Za ně Rychard nepovažuje ani tak fakt politické revitalizace tzv. postkomunistických sil, ale za větší nebezpečí má stále sílící elementy chování a postupů vládnoucí koalice, které připomínají minulý režim a mohou vést $\mathrm{k}$ mobilizaci „druhéc strany podle kritéria, jež vedlo ke zrodu Solidarity. Č́m nutnější to bude pro zastavení pokusủ představitelủ minulého pořádku, tím škodlivější to bude pro budoucnost zreformovaného institucionálního řádu. Dělení podle starých genealogii má totiž jen málo společného s fundamentálním dělením na síly proreformní a síly antireformní.

\section{Formováni nové sociálni struktury}

Touto problematikou se ve svém vystoupení velmi obsáhle zabýval dlouholetý badatel sociální struktury, i u nás dobře známý (mj. knihou Třídy, vrstvy a moc, jejiž český překlad vyšel roku 1969) Wlodzimierz Wesolowski z Institutu filozofie a sociologie Polské akademie věd. Jeho př́spěvek Procesy vytváření tříd $\mathrm{v}$ teoretické perspektivě má dvě části, $\mathrm{z}$ nichž prvni nastiňuje obecné paradigma úvah o třídních strukturách společností západní civilizace a druhá je věnována popisu a rozboru přeměn jednotlivých tříd současné polské společnosti. Vzhledem $\mathrm{k}$ zaměřeni naši informace budeme referovat pouze o části druhé, $v$ níž autor postupně analyzuje vytváření tř̌́dy kapitalistů, formování střední třídy, přeměny inteligence, dekompozici dělnické třidy a změny uvnitř rolnictva.

Wesołowski piše, že třída buržoazie se v Polsku rodi doslova před očima a že vezme- 
me-li v úvahu její existenci v období mezi 1 . a 2 . světovou válkou, dalo by se hovořit o její ,restituci“. Avšak generační, kulturní i majetková kontinuita byla natolik přerušena, že je vhodnějši, nazveme-li celý proces novým vytvářením této třídy.

Podle autora se třída kapitalistů rodí z pěti dřive existujicích skupin a zdrojů:

1. z lidí, kteří mají ,nomenklaturni" minulost, jež patři k ,pozičním“ zdrojủm. V publicistice je tento pưvod dnešních polských kapitalistů uváděn nejčastěji, i když není snadné stanovit proporce firem, které takto vznikly. Zmíněná cesta se nesporně projevila $\mathrm{v}$ průmyslové velkovýrobě a ve velkoobchodu, kde se kapitalisty stali bývalí ředitelé podnikủ zahraničního obchodu i některých továren a podniků služeb. Mocenské pozice se zde efektivně přeměnily ve zdroje bohatství. Bylo $k$ tomu ovšem zapotřebi disponovat i určitými čistě osobními kvalitami, a to pružností, schopností riskovat $\mathrm{i}$ aktivním poměrem $\mathrm{k}$ vlastnímu osudu;

2. z těch, kteři vytvořili firmu díky osobní energii a které Wesołowski nazývá selfmademany. Důležitou roli přitom hrál vlastni talent stejně jako vysokoškolské vzdělání. Pomocným faktorem byla sociální síla výchovy, povolání otce a sociálně profesionální sítě vztahủ, jakož i specifické rozšírení „sociálního kapitálu“ na možnost cestovat i na znalost kapitalistického světa. Z hlediska některých zvláštních znaků se tato kategorie dělí na dva podtypy: a) na lidi spolehlivé, poctivé a nepostrádající prospolečenskou orientaci, b) na spekulanty a egoisty se sklonem k jakékoli nepoctivosti;

3. ze současných ,expertư ${ }^{\text {‘c }}$ kteří působí jako vlastníci konzultačnich firem a čerpají dosti vysoké zisky ze služeb prodávaných různým státním institucím, ministerstvům, bankám a zahraničním podnikủm. V těchto firmách pracuji právníci a ekonomové, bývalí podnikoví právní poradci, profesoři ekonomických fakult i mladí absolventi nedávno otevřených domácích manažerských škol a zahraničních univerzit. Jejich společným zdrojem jsou vysoké kompetence, ,z zưle vlády“ však získávají i velké zdroje moci, prinejmenším hospodářské, jakož i akcie a vysoké odměny, tudiž značné zdroje ekonomické. Tato technokratická vrstva má šanci stát se velkou a reálnou hospodářskou silou;
4. z lidí, které Wesołowski nazývá vynálezci. Ti sehráli velkou roli už $\mathrm{v}$ raných fázích evropského a amerického prủmyslu (např. Winchester, Daimler a Bayer). V současnosti jsou jimi chemici a počítačoví odborníci (tvůrci nových výrobků a technologií i chemických syntéz, kteří se stali kapitalisty). V Polsku se dnes talent projevený $\mathrm{v}$ konstrukci nových mechanismů a zařizení, jakož i chemických syntéz stává základem pro vytvoření vlastního podniku. Nedochází $k$ tomu ve velkém měřit$\mathrm{ku}$, nicméně tento typ kariéry se objevil mezi bývalými pracovníky technických vysokých škol, výzkumných ústavů Polské akademie věd i mezi absolventy fakult exaktních věd. $\mathrm{V}$ jistém smyslu je to podle Wesołowského nejušlechtilejši typ kapitalistické „kariéry“;

5. z kapitalistů, kteř́ jimi v zárodku fakticky byli již za minulého režimu. Mnoho $\mathrm{z}$ nich systematicky zvětšovalo (zejména v 70. a 80. letech) svůj osobní majetek, i když nikoli nutně pod vlastním jménem. Wesołowski je souhmně nazývá lidmi obdařenými přirozeným kapitalistickým instinktem a dokonce je v jistém smyslu považuje za dnešní ztělesnění puritánů 17 . století, kterým bylo souzeno pracovat ve výjimečně nepřiznivých podmínkách. Jde o dřívější kategorii „soukromě hospodařících" ${ }^{\text {"s }}$ mezi nimiž ovšem existovali i lidé usilující o snadné obohacení v důsledku nedostatků socialistického zásobování a trhu. Proto to není kategorie jednolitá.

Wesołowski konstatuje, že vzhledem $\mathrm{k}$ různorodosti kruhủ, z nichž se kapitalistická třída rekrutuje, není zatím př́liš integrovaná a nevytváíi se v ní vykrystalizovaný a stejnorodý typ podnikatele. Nemá ani velký zájem o problematiku své skupinové totožnosti.

V dalši části příspěvku se autor zabývá formováním střední trrídy, do niž řadí ty, kteří pracuji se svými vlastními prostředky. Tato třída se rychle rozvíjí a početně roste, přičemž dominuje $\mathrm{v}$ oblasti malého a středního obchodu i ve službách. Úspěšně využívá tři zdrojů: drobného kapitálu, technických, ekonomických a sociálních znalostí trhu, výrobků i obchodních smluv, a konečně schopnosti riskovat. Mnoho príslušníků této trrídy se rekrutuje $\mathrm{z}$ techniků, prodavačủ a úředníků, kterým pod vlivem transformačních změn hrozila ztráta práce nebo drastické snížení výdělků.

Tato třída stoji podle Wesołowského před vážnými problémy, jako je utvářeni konkrétní- 
ho vztahu $\mathrm{k}$ akumulaci kapitálu, definice vlastních skupinových zájmů, iniciování procesů vnitřní integrace a tvorba svého étosu. Politická orientace jejích přislušníků není zatím jasná. Autor připouští, že mohou směřovat jak $\mathrm{k}$ liberalismu, tak $\mathrm{k}$ populismu, př́padně i etatismu.

$\mathrm{K}$ podstatným změnám dochází uvnitř inteligence. Jde o procesy různorodé, výrazně ovlivňujicí i další složky sociální struktury. Wesołowski se zmiňuje o třech: 1. rekrutují se z ní kapitalisté i střední třída, čímž se změnšuje její počet; 2. stává se méně etatistickou a více tržní, což ji sbližuje s trrídami velkých i menších podnikatelů; 3 . přetváŕí charakter svých kulturních zdrojů. Jeji hlavní zdroj, jímž je vědění, se stává experimentálnějši a méně humanitní.

Neznamená to však, že inteligence jako společenská skupina mizí. Jádro jejích profesí je nutné v každé civilizaci, která dosáhla určitého vývojového stupně v oblasti technologie, organizace sociálního života a diferenciace činností. Inteligence si také uchovává svou kulturní roli, nebot' je tvůrkyní i propagátorkou symbolů i smyslu života. Vědění, jímž disponuje, jí usnadňuje prístup $\mathrm{k}$ bohatství a moci. $Z$ inteligence se vyděluje tenká vrstva intelektuálů a politiků.

Polská inteligence mívala ve svém étosu prvky kolektivismu, respektive komunitarismu, a to proto, že ideově reprezentovala národ bojující o nezávislost a vlastní stát. Později si kritikou komunistického programu udržovala posláni kolektivního intelektuála a vůdce společnosti. Vzhledem $\mathrm{k}$ tomu, že se uplatňuje např. $v$ nemocnicích a ve školách, je orientována na spoluvytváření a sledování státnich koncepci, bez nichž $\mathrm{v}$ soudobé civilizaci nemůže mnoho sfér života fungovat. Je tudíž do jisté míry orientována etatisticky. Nová doba způsobuje, že některé její kategorie se budou muset orientovat tržně, což povede $\mathrm{k}$ individualismu. Tento proces, jenž ji bude sbližovat se střední třídou a s třídou velkých vlastníků, však neproběhne bez konfliktů. Je možné, že $v$ důsledku všech těchto přeměn sehraje inteligence $\mathrm{v}$ budoucnu jednu ze dvou rolí: bud' díky svým poznávacím perspektivám, ale i díky zdrojủm odborného vědění to bude role zprostředkující a sbližující různá hlediska, což očekával Mannheim, nebo zvolí jednu zvlášt- ní koncepci společného zájmu, čímž se stane více stranickou.

Doslova bouřlivými přeměnami prochází podle Wesołowského dělnická třída, přičemž jde o změny vnitřně rozporné a ambivalentní. $Z$ třídy, která tvořila centrum sociálněpolitického hnutí s obrovskou mocí (Solidarita), se musela přeměnit v partikulární třídu ztrácející společenskou moc

Reformní procesy mají pro dělnickou třidu dva základní důsledky: postupně se zmenšuje její počet a dochází $k$ její vnitřní dekompozici. Jeji různé složky začínaji mít rủzné osudy. Jedni odcházejí a stávají se trvale nezaměstnanými, druzí z jiných závodů se nemají špatně nebo dokážou ekonomické těžkosti překonat. Perspektivy obou však nejsou dlouhodobě definovány. Budoucnost je otevřená, ale nejistá, u mnoha lidí vyvolává strach. Někteři dělníci využívaji technickou kvalifikaci a sebedưvěru, zakládají vlastní firmy a stávají se drobnými podnikateli.

Vnitřní fragmentarizaci dělnické třídy doprovází dekonstrukce starých zájmů. Dělníci prosperujicích závodů mají již jiné zájmy než dělníci závodů, kterým hrozi uzavření. Podstatnou skutečností je však velká solidarita dělníků některých odvětví, která byla privilegována $\mathrm{v}$ minulém režimu (hornictví, hutnictví a železnic).

S dekompozicí souvisí podle Wesołowského obecnější jev, a to skutečnost, že dělnická třída nevede ofenzívní boje neboli aktivní spory o nová řešení (výjimkou jsou spory o některé aspekty privatizace). Vede spiše boje defenzívní o udržení životní úrovně svých rodin, o udržení zaměstnání, sociální ochrany a vlivu na ekonomická rozhodnutí vlády. Je to úplně jiná strategie, než kterou uplatňuje třída, jež je na vzestupu a jejiž vliv se zvětšuje.

Dělnická třída neprojevuje ani jasné sociálně-politické postoje. Její příslušníci nejsou přívrženci jedné stranické orientace ani několika orientací podobných. Obdobně jako jiné třídy netvoři základnu ani stálé voličstvo určitých stran. Wesołowski to považuje za přechodný jev. Dělníci vyjadřují své snahy a požadavky téměř výlučně prostřednictvím odborů. Autor se domnívá, že nevykrystalizovanost politických postojủ odráži nejistotu týkající se realizace běžných i dlouhodobých zájmů. Dělníci nevědí, jak se jejich zájmy budou 
vyvíjet a která strana by mohla napomáhat jejich uskutečnění.

Patrně proto se také dělníci od politiky výrazně distancuji a tento jev má tendenci se upevňovat. Jedním z jeho aspektů je, že přestávaji vyhledávat informace o ekonomických, sociálních a politických otázkách a podle vlastního hodnocení ztrácejí schopnost hospodářské a politické jevy percipovat.

Dělníci nejsou proti tržnímu hospodářství a odmítaji model fungování podniku reálného socialismu, chtěli by však, aby byla vytvořena taková verze tržní ekonomiky, $\mathrm{v}$ níž by se mohli podílet na řízení. Jejich názory jsou doprovázeny celkovou atmosférou konzervativního fatalismu. Budoucnost se jim jeví nepříznivě, a $z$ toho důvodu se vyslovují spíše pro to, aby změny nebyly príliš rychlé a aby se jich dalši řešení dotýkala méně bolestivě než dnes. Nejpřiznačnějším projevem zmíněného fatalismu je podle Wesolowského skutečnost, že značné části dělníků (podle některých výzkumů více než $40 \%$ ) je lhostejné, kdo je u moci, a téměr polovina $z$ nich je toho názoru, že v jejich závodě nikdo dobře nereprezentuje jejich zájmy.

Za podstatný znak celospolečenské situace Wesołowski považuje, že kromě tendence stávkovat se u dělníků neprojevuje výrazná tendence podílet se na vytváření struktur občanské společnosti. Není např. slyšet o tom, že by se $\mathrm{v}$ jakékoli oblasti života zakládaly dělnické spolky.

Negativně působícím faktorem bude pravděpodobně stálá existence nezaměstnaných. Ti neopustí trídu, budou její specifickou,,podtrídou", a to ve dvojím smyslu: jako profesionálně nestabilizované osoby žijící v širších rodinách a jako osoby a rodiny bydlíci v sousedství. Mohou se stát i „mimotřídním“ fragmentem sociální struktury, s nímž jiné třídy přestanou být solidární. Spolu s vytvářejícími se skupinami zdeklasovaných rolníků mohou trvale nezaměstnaní lidé negativně ovlivňovat celospolečenskou atmosféru.

Analýzu přeměn rolnické třídy uvozuje Wesołowski konstatováním, že to byla $\mathrm{v}$ Polsku jediná třída, která si uchovala soukromé vlastnictví půdy $\mathrm{i}$ jiných pracovních prostředků a která prodávala své produkty v kvazitržním systému. Transformace směřujicí $\mathrm{k}$ plnému uznání práv soukromého vlastnictví a $\mathrm{k}$ dominaci tržní regulace vytvořila nové podmínky, jež byly řadovými přislušníky třídy předvídány a očekávány jen zčásti. Objevuji se totiž hluboké rozpory mezi vývojem ke kapitalismu a mezi dosahováním blahobytu rolníky, které vyplývají ze střetu rozdrobené a zaostalé agrární kultury s velkou konkurencí na mezinárodních trzích se zemědělskými výrobky.

Jako reakci na tento střet lze podle Wesolowského očekávat tři vývojové tendence:

1. petrifikaci existujíci situace, která může pro nejbližší léta rozptýlit obavy rolníkủ z budoucnosti, ale žádný $z$ problémủ nevyřeší. Ochrana aktuálních zájmů rolnictva, i když se zdá být dnes nutná, hraje konzervativní roli. Nebezpeči dlouhodobého uchování tradiční charakteristiky třídy i jeji politické orientace je mezi rolnictvem největší a nesrovnatelné $\mathrm{s}$ jinými třídami;

2. radikální modemizaci struktury vynucenou ekonomickými okolnostmi, ale odmítanou mnoha přislušníky třídy. Záměr definitivně překonat minulost často operuje vizí drastických změn ve struktuře rolnického vlastnictví, především vizí eliminovat malá hospodářství a zvětšit hospodářství ekonomicky silná. Model takových změn je však podle Wesolowského těžko realizovatelný, protože i těm nejbohatším rolníkům se nedostává kapitálu. Kromě toho neřeší otázku rolníků vyhnaných z půdy. Moderni průmysl, který sám „produkuje“ nezaměstnanost, nemá potenciál, který by mohl pracovní síly uvolněné ze zemědělství zaměstnat. Je tudiž problematické, dovozuje autor, zda je model rychlé transformace rolnického vlastnictví možný a zda je společensky akceptovatelný;

3. novátorské spojení modernizace agrární struktury se zvláštním typem industrializace vesnice, jež by spočívalo ve vybudování zemědělsko-potravinářského průmyslu na venkově. Takový vývoj by zajistil pracovní mista i růst př́jmů zemědělského obyvatelstva, jakož i lidí zaměstnaných v novém typu průmyslové činnosti. S ohledem na kapitálové náklady nutné pro zavedení kooperativních forem práce i pro spojování kapitálových zdrojů se může podle Wesolowského ukázat jako nutné vytváření nových forem družstevnictví. Znamenalo by to návrat ducha kooperace na polskou vesnici. 
Autor upozorňuje na některé závažné psychické bariéry tkvící $\mathrm{v}$ kultuře rolnické práce, které stojí uvedené modernizaci polského zemědělství v cestě. Rolníci jsou zvyklí na těžkou práci, jejíž dobu určují sami, a nikoli způsobem, který by byl vždy vnitřně disciplinovaný. Moderní zemědělství i průmysl vyžadují větší „časovou“ kázeň. Rolníci se při obdělávání půdy řídí tradicí, zatímco moderní zemědělství vyžaduje neustálé inovace. Orientace na vnější svět je už sice mezi rolníky otevřenějšsi, nicméně nadále jsou vůči jevům neosvojeným vlastní zkušeností spíše nedůvěřiví. Étos života zakořeněný v práci na poli a $\mathrm{v}$ rodinném hospodářství je ve srovnání $\mathrm{s}$ étosem všech ostatních tříd hủře překonatelný. Vesnice rovněž disponuje slabými kapitálovými zdroji a rolníci maji většinou nízké vzdělání. Wesołowski proto klade otázku, zda vnější prostředí bude ve vztahu $\mathrm{k}$ rolnickému prostředí a kultuře dostatečně silné a zda bude disponovat dostatečnými prostředky, aby přeměnilo tradiční kulturu práce $\mathrm{v}$ kulturu moderní. Podněty tohoto druhu přicházely totiž $\mathrm{i}$ v západní Evropě do zemědělství vždy zvnějšku.

\section{Změny v hodnotově normativni sfére}

Touto tematikou se patrně nejsoustavněji zabýval príspěvek pracovnice Institutu filozofie a sociologie Polské akademie věd Aldony Jawlowské nazvaný Řád, nebo rozpad? Autorka $\mathrm{v}$ něm vyslovuje pochybnosti o dosti všeobecně rozšíreném názoru, že nový normativní rád v Polsku se právě rodí a že úkolem sociologů je ,zachyceni“ tohoto procesu a analýza jeho podmínek a průběhu. Zmíněný názor obsahuje totiž předem přijatý předpoklad, že společenské a kulturní změny postupují od absence rádu čili od „axiologického vakua“ $\mathrm{k}$ řádu. Důsledkem mínění, že polská společnost i jiné tzv. postkomunistické společnosti se jaksi přirozeně nebo pod vlivem historických zákonů vyvíjejí správným směrem (pořádek na rozdíl od chaosu bývá obvykle hodnocen pozitivně), je volba teoretické orientace, podle níž perspektiva řádu je nejlepší organizující perspektivou zkoumání transformace. Podle autorky si ale lze představit úplně opačný směr přeměn, tj. od ř́du $\mathrm{k}$ jeho $\mathrm{ab}$ senci, $\mathrm{k}$ rủzným formám destrukce známých normativních $\mathrm{i}$ hodnotových pořádků považo- vaných za stabilní. Perspektiva absence řádu, chaosu je tudíž jako teoretický předpoklad i jako pravděpodobná skutečnost, která už existuje a která se rodí, rovněž možná.

Dynamika změn $v$ axionormativní sfére je totiž podle Jawłowské vždy, a nikoli pouze v naší době, oscilací mezi rádem a jeho absencí. Autorka se domnívá, že dnes v Polsku rozpad této sféry nad vytvářením normativního řádu dominuje, přičemž oblasti nepředvídatelné a nedeterminované všeobecně jasnými normami jsou rozsáhlejší než ty, $v$ nichž se badatel i „běžný člověk ${ }^{c c}$ může pohybovat $s$ jistotou. Je tomu tak nejen proto, že žijeme v tzv. postkomunistické společnosti, ale také v důsledku hlubokých změn v globálním měřitku. Reálný socialismus, zejména ke konci své existence, byl velmi vzdálen od dokonalého ,monocentrického pořádku". Eroze ideologie, na níž byl tento rád založen, trvala přece dlouho a devalvace hodnot, nesoulad přesvědčení a jednání, úpadek závazné moci společenských a etických norem byl už dávno tématem výzkumů polských sociologů. Avšak společenská skutečnost, jakkoli byla často vnímána jako absurdní, byla stejně často chápána a hodnocena právě svým vztahem $\mathrm{k}$ hodnotám ,socialistického humanismu“. Z hlediska dneška už lze ř́ci, že pro mnoho lidí nebyly tyto hodnoty něčím pouze vnějším a vnuceným. Konečný pád systému, považovaného téměř do poslední chvíle i experty za relativně stabilní, uspíšil již mnoho let trvající destrukci norem a hodnot a uvedl do pohybu nové procesy.

Současná etapa rozpadu je podle Jawłowské výsledkem dvojího zhroucení. Po pádu levicové utopie došlo $\mathrm{i} k$ pádu utopie pravicové s její vizí všeobecného blahobytu a dokonalého řádu, jichž by se dosáhlo okamžitě díky zázračné a seberegulující síle svobodného trhu. Tzv. postkomunistická společnost byla tudíž zbavena druhého vztažného bodu nezbytného $\mathrm{k}$ hodnocení a orientaci ve světě společenských norem a hodnot. Těmi přece byly s hodnotami socialistického humanismu jakoby souběžné hodnoty zmytologizované západní kultury. Rozpad hodnot, na nichž byly obě protikladné koncepce společenského ř́du založeny, trvá i nadále a způsobuje zmatek $\mathrm{v}$ mnoha oblastech jak soukromého, tak veřejného života. Za jeho některé symptomy 
považuje autorka napr. nejasnost významů slovníku užívaného v politickém diskurzu, nečitelnost symbolů, jež nás obklopuji, absenci víry v ,lepši zítřek ${ }^{“} \mathrm{i}$ pád všech autorit.

Prohlubování absence řádu napomáhá nejen specifická politická a ekonomická situace tzv. postkomunistických zemí, ale rovněž civilizační a kulturní změny probíhajicí v zemích západních. Autorka má na mysli to, že se vyčerpaly hybné silly kulturní formace založené na hodnotách rozumu, pokroku, pravdy a všeobecné emancipace. Zhroucení „velkých vyprávěni" (Lyotard) či ,regulativních ideji (Stróźewski), tvořících rámec, v němž se konstituoval axionormativní pořádek, způsobuje že odvolávat se na Západ jako na vzor a zdroj hodnot ztrácí smysl. Je totiž velice pravděpodobné, že v dnešních západních společnostech „vratká lávka konvencí přikrývá propast tam, kde by měly být základy"s (Bauman).

Formování axionormativního řádu nenapomáhá kultura ovládaná supermédii a novými komunikačnimi prostředky. Nevytváří totiž relativně stálé společenské vztahy založené na známých a lidmi sdílených pravidlech, nýbrž nahodilé a nestabilní systémy, které nejsou realizací normy, ale výsledkem individuální volby. Mnoho badatelů upozorňuje na nevyhnutelnost ,ztráty reality ${ }^{c c}$, která vede $\mathrm{k}$ tomu, že je stále těžší opustit svět vytvářený médii. Autorka je přesvědčena, že dnešní zmatek $v$ oblasti norem a hodnot není přechodný jev, charakteristický jen pro období systémové transformace, která skončí konstituováním nového řádu. Hlavní problém soudobé polské společnosti $\mathrm{v}$ axionormativní sfére spatřuje Jawłowská nikoli v tom, že by došlo $\mathrm{k}$ pádu pozitivních ideji a hodnot, jež se donedávna těšily společenské autoritě. Ty jsou $\mathrm{v}$ textech kultury stále přitomny a mohou díky tomu kdykoli ožít. Tím, co se fakticky rozpadá a zaniká, nejsou totiž hodnoty, ale ,axionormativní řád“, který jim umožňuje, aby formovaly sociální chování. Zmíněné hodnoty ztratily dnes závaznou sílu, jinak řečeno, nemaji oporu $\mathrm{v}$ normách. A naopak, absence rádu plyne $\mathrm{z}$ toho, že normotvorný proces je odtržen od hodnot, že došlo $\mathrm{k}$ roztržce mezi hodnotami chápanými jako nejvyšši ideje a mezi pravidly a vzory jednání. Zdrojem norem se stává vrtošivý ,zákonodárný orgán“ nedisponující společenskou autoritou, proměnlivá móda, hrdinové televiz- ních př́běhů nebo také prostě společenská praxe poukazující na účinnost či neúčinnost určitých vzorů jednání.

Jako príklady oblastí, kde dnes můžeme pozorovat spíše rozpad norem než vytváření nového řádu, uvádí autorka veřejnou sféru, $v$ níž politickým diskurzem neustále deklarované hodnoty a normy nemaji větší praktický význam, dále sféru hospodářské činnosti, $\mathrm{v}$ níž souběžně $\mathrm{s}$ normotvorným procesem dochází k porušování veškerých norem a pravidel, a konečně soukromý život jedinců, $v$ němž změny nesměřuji $\mathrm{k}$ nahrazení jednoho řádu jiným, ale $\mathrm{k}$ individualizaci lidského chování nepodřizeného normám a „vyjednaného" $\mathrm{s}$ jinými partnery interakce.

Sociálně nebezpečnou reakcí na absenci sdílených a závazných norem je podle autorky libovủle v chování lidí neboli ,beznormativní in-

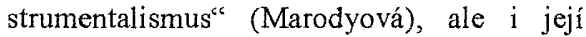
protiklad, jímž se může stát nacionalistický nebo náboženský fundamentalismus. Formou útěku ze světa chaosu, praktikovanou zejména mládeži, jsou tzv. étosové skupiny, které tvoři náboženské menšiny, $v$ nichž je celý život jedince uspořádán podle vybraných hodnot. $\mathrm{V}$ realitě, která se jeví jako nejasná a nepředvídatelná, se hledá pomoc i ve světě paranormálních jevů.

Podle Jawłowské se objevují rovněž pokusy o vytváření alespoñ dilč́iho řádu, tj. takové, jež se snaži uspořádat přinejmenším některé složky reality. Různé formy axionormativního řádu se vytvářejí také uvědomělou hodnotově normativní činností různých sociálních subjektů, např. katolické církve, ekologických hnutí a profesionálních skupin.

Přes tyto pokusy nevidí dnes autorka žádná centra, která by byla $s$ to prijít s návrhem takového normativního řádu, jenž by získal všeobecný souhlas. To však neznamená, že by polské společnosti hrozila katastrofa a ,anarchie". Nestabilita normativních řádů i jejich nezakořeněnost ve vyšších hodnotách nemůže totiž vést ke snížení výkonnosti ,společenského mechanismu“. Autorku neznepokojuje ani tak neúčinnost, ale spišse instrumentálnost tohoto druhu normativního uspořádání. Normotvorný proces odtržený od vyšších hodnot usnadnuje sice pohyb ve světě, ale nevede $\mathrm{k}$ tomu, aby tento pohyb měl hlubší smysl.

Jan Sedláček 